\title{
Natural Radioactivity Measurement and Assessment of Radiological Hazards in Some Building Materials Used in Bangladesh
}

\author{
M. Azmary Khatun1, J. Ferdous ${ }^{2}$, M. M. Haque ${ }^{1^{*}}$ \\ ${ }^{1}$ Department of Physics, University of Rajshahi, Rajshahi, Bangladesh \\ ${ }^{2}$ Health Physics Division, Atomic Energy Center (AEC), Dhaka, Bangladesh \\ Email: *mhpdru@gmail.com
}

How to cite this paper: Khatun, M.A., Ferdous, J. and Haque, M.M. (2018) Natural Radioactivity Measurement and Assessment of Radiological Hazards in Some Building Materials Used in Bangladesh. Journal of Environmental Protection, 9, 1034-1048.

https://doi.org/10.4236/jep.2018.910064

Received: June 7, 2018

Accepted: September 4, 2018

Published: September 7, 2018

Copyright $\odot 2018$ by authors and Scientific Research Publishing Inc. This work is licensed under the Creative Commons Attribution International License (CC BY 4.0).

http://creativecommons.org/licenses/by/4.0/

\begin{abstract}
The radioactivity concentrations of ${ }^{226} \mathrm{Ra},{ }^{232} \mathrm{Th}$ and ${ }^{40} \mathrm{~K}$ in 24 samples of natural and manufactured building materials commonly used in Bangladesh were measured using HPGe gamma ray spectrometer. The results in the present study were compared with the world average and also with the reported data available in literature. The radium equivalent activity, the absorbed dose rate, annual effective dose, external and internal hazard indices, gamma index, alpha index, annual gonadal dose equivalent and excess lifetime cancer risk were also evaluated to assess the potential radiation hazards associated with these building materials. All samples under investigation were found to be within the recommended safety limit and do not pose any significant radiation hazards. This study can be used as a reference for more extensive studies of the same subject in future.
\end{abstract}

\section{Keywords}

Natural Radioactivity, Building Materials, HPGe Detector, Radiation Hazards

\section{Introduction}

Measurement of natural radioactivity concentrations in building materials has fundamental importance in evaluating significant gamma dose indoors, due to their natural radionuclide contents. All building materials are mostly composed of rock and soil containing natural radionuclides such as ${ }^{238} \mathrm{U}$ and ${ }^{232} \mathrm{Th}$ decay series and ${ }^{40} \mathrm{~K}$. These natural radionuclides and their decay products, also called terrestrial background radiation (such as ${ }^{214} \mathrm{~Pb},{ }^{214} \mathrm{Bi},{ }^{212} \mathrm{~Pb},{ }^{208} \mathrm{Tl},{ }^{228} \mathrm{Ac}$, etc.), may cause both external exposure due to their direct gamma radiation and internal 
exposure from radon gas. Various hazard parameters, such as radium equivalent activity $\left(R a_{\text {eq }}\right)$, the absorbed dose rate $(D)$, annual effective dose $\left(D_{\text {eff }}\right)$, external $\left(H_{\mathrm{ex}}\right)$ and internal $\left(H_{\mathrm{in}}\right)$ hazard indices, gamma index $\left(I_{\gamma}\right)$, alpha index $\left(I_{\alpha}\right)$, annual gonadal dose equivalent (AGDE) and excess lifetime cancer risk (ELCR) play a significant role to assess the potential radiation hazards posed by these building materials. In the ${ }^{238} \mathrm{U}$ series, the decay chain segment starting from ${ }^{226} \mathrm{Ra}$ is radiologically the most important and, therefore, reference in the present study has been made to ${ }^{226} \mathrm{Ra}$ instead of ${ }^{238} \mathrm{U}$. The world-wide average concentrations of ${ }^{226} \mathrm{Ra},{ }^{232} \mathrm{Th}$ and ${ }^{40} \mathrm{~K}$ in the earth crust are about $40 \mathrm{~Bq} \cdot \mathrm{kg}^{-1}, 40$ $\mathrm{Bq} \cdot \mathrm{kg}^{-1}$ and $400 \mathrm{~Bq} \cdot \mathrm{kg}^{-1}$, respectively [1].

There has been increased trend of public worldwide in using ceramic tile, stone, marble, granite, etc., due to their polished surface, decorative and different attractive colors, as building materials. The ceramic tiles are generally made of a mixture of different raw materials including clays, quartz materials and feldspar that has been pressed into shape and fired at high temperature. The marble, on the other hand, is a metamorphic rock composed of recrystallized carbonate minerals, most commonly calcite or dolomite. It is extracted from the mountains and after mining it is transported to marble factories in various cities. Granite is the best-known igneous rock. It is composed mainly of quartz and feldspar with minor amounts of mica, amphiboles, and other minerals. A common opacifying constituent of glazes, applied to these materials, is zircon that may cause natural radioactivity concentration significantly higher than the average values for building materials [2] [3] [4].

The worldwide average indoor effective dose due to gamma rays from building materials is estimated to be about $0.4 \mathrm{mSv}$ per year [5]. Radiation exposure of the population can be increased appreciably by the use of building materials containing this normal levels of natural radioactivity. It has been demonstrated in various studies that, if building materials with high natural radioactivity concentration are employed, dose rates indoors will be elevated accordingly [2]. Knowledge of basic radiological parameters, such as radioactive contents and their activity concentrations in building materials is, therefore, very much important in the assessment of possible radiation exposure of the population, as most people spending approximately $80 \%$ of their lifetimes surrounded by building materials at home and/or at the office [6] [7] [8].

The specific activities of ${ }^{226} \mathrm{Ra},{ }^{232} \mathrm{Th}$ and ${ }^{40} \mathrm{~K}$ in the building raw materials and products mainly depend on geological and geographical conditions as well as geochemical characteristics of those materials [1] [9]. To date, a great attention has been paid to determining radionuclide concentrations in building materials in many countries [3] [9]-[19]. However, for Bangladesh, there is only a few experimental data [7] [20] [21] [22] available in literature regarding the radioactivity of building materials. Mollah et al. [20] found a somewhat higher level of activity in building materials than in other countries. Roy et al. [21] later carried out an extensive study on the radioactivity in various types of brick samples fabricated and used in Dhaka City and its suburbs. The activity levels in 
brick samples were found to be consistent with some of that reported in literature. Recently, Asaduzzaman et al. [7] and Roy et al. [22] investigated some building materials (brick, sand and cement). The aim of the present research is not only the determination of natural radioactivity in some building materials but also the evaluation of the radiological hazard parameters such as $R a_{\text {eq }}, D, D_{\text {eff }}$, $H_{\text {ex }}, H_{\text {in }}, I_{p} I_{\alpha}, \mathrm{AGDE}$ and ELCR. The present results of radioactivity concentrations of ${ }^{226} \mathrm{Ra},{ }^{232} \mathrm{Th}$ and ${ }^{40} \mathrm{~K}$ and their associated radiological hazards parameters mentioned above were compared with the available experimental data.

The rest of this paper has been organized as follows. Section 2 outlines the experimental procedure. In Section 3, we have presented and compared our results systematically with available measurements. Section 4 contains the conclusion on the present findings.

\section{Experimental Procedure}

\subsection{Sample Collection and Preparation}

A total of 24 samples of 5 different kinds of building materials used for dwelling in Bangladesh were collected from the dealers. Sample preparation and all radioactivity measurements were performed in the Health Physics Division, Atomic Energy Center (AEC), Dhaka, Bangladesh. The building materials investigated are stone 5 samples, sand 5 samples, cement 5 samples, ceramic tiles 7 samples and marble 2 samples. The samples each about $1 \mathrm{~kg}$ in weight were dried in an oven at about $110^{\circ} \mathrm{C}$ to ensure that moisture is completely removed. Each of the dried samples (except cement) was grounded to fine powder in an agate motor separately. The powdered samples were then sieved using a fine aperture mesh screen (mesh size $2 \mu \mathrm{m}$ ) in order to remove extraneous items like plant material, roots, pebbles etc. and to obtain a fine grained sample that would present a uniform matrix to the detector. Finally, the grounded samples, approximately 250 - $550 \mathrm{gm}$ of each, were transferred to cylindrical plastic-container $(6.5 \mathrm{~cm}$ diameter $\times 7.5 \mathrm{~cm}$ height $)$. The containers were then labeled properly and sealed tightly, rapped with thick vinyl tapes around their screw necks. The samples were stored for at least 4 weeks before counting in order to attain secular equilibrium.

\subsection{Gamma Spectroscopic Measurements}

To qualitatively identify the contents of radionuclides in studied building materials and to quantitatively determine their activities, all prepared samples were subjected to gamma spectral analysis with a counting time of $5000 \mathrm{~s}$. Gamma spectroscopic measurements were performed by means of a coaxial ORTEC HPGe detector with a relative efficiency of $28.2 \%$ and an energy resolution of $1.67 \mathrm{keV}$ FWHM at the $1332.5 \mathrm{keV}$ peak of ${ }^{60} \mathrm{Co}$. The detector was employed with adequate lead shielding to reduce the background radiation from various natural radiation sources and to isolate from other radiation sources 
used in nearby surroundings.

For energy calibration and relative efficiency calibration of the gamma spectrometer some monoenergetic gamma sources ${ }^{137} \mathrm{Cs}$, ${ }^{60} \mathrm{Co}$ and ${ }^{40} \mathrm{~K}$ were chosen due to a wide range of gamma-ray energies emitted over the entire energy range of interest. The content of ${ }^{226} \mathrm{Ra}$ was measured using the characteristic $\gamma$ lines of its decay products, including those of ${ }^{214} \mathrm{~Pb}(295 \mathrm{keV})$, ${ }^{214} \mathrm{~Pb}(352 \mathrm{keV}),{ }^{214} \mathrm{Bi}(609 \mathrm{keV})$ and ${ }^{214} \mathrm{Bi}(1120 \mathrm{keV})$. Similarly, the gamma-ray lines of ${ }^{212} \mathrm{~Pb}(239 \mathrm{keV}),{ }^{208} \mathrm{Tl}(583 \mathrm{keV}),{ }^{228} \mathrm{Ac}(911 \mathrm{keV})$ and ${ }^{228} \mathrm{Ac}(969 \mathrm{keV})$ were used for ${ }^{232} \mathrm{Th}$. The activity of ${ }^{40} \mathrm{~K}$ was determined from its intensive gamma-line at $1461 \mathrm{keV}$. No ${ }^{137} \mathrm{Cs}$ line was obtained at $661.7 \mathrm{keV}$. The activity concentration of individual radionuclides was calculated from the following analytical expression [23]:

$$
A\left(\mathrm{~Bq} \cdot \mathrm{kg}^{-1}\right)=\frac{N}{\varepsilon_{\gamma} \times \rho_{\gamma} \times T_{s} \times M}
$$

where $A$ is the specific activity in $\mathrm{Bq} \cdot \mathrm{kg}^{-1}$ of each radionuclide in the sample, $N$ is the net number of counts in the resulting photo-peak, $\varepsilon_{\gamma}$ is the detector efficiency of the specific gamma-ray, $\rho_{\gamma}$ is the intensity at the corresponding gamma-ray energy, $T_{s}$ is the sample counting time in seconds and $M$ is the mass of the sample in $\mathrm{kg}$. Error associated with every calculation was measured by standard deviation equation.

The background spectrum was used to determine the minimum detectable activity concentration (MDAC) of $0.35 \mathrm{~Bq} \cdot \mathrm{kg}^{-1}$ for ${ }^{226} \mathrm{Ra}, 0.64 \mathrm{~Bq} \cdot \mathrm{kg}^{-1}$ for ${ }^{232} \mathrm{Th}$ and $2.2 \mathrm{~Bq} \cdot \mathrm{kg}^{-1}$ for ${ }^{40} \mathrm{~K}$ at the $95 \%$ confidence level. The equal counting time for both background and sample measurement was chosen to minimize the uncertainty in the net counts. The combined uncertainty of the activity concentration was estimated using [7]:

$$
\Delta A=A \sqrt{\left(\frac{\Delta N}{N}\right)^{2}+\left(\frac{\Delta \varepsilon_{\gamma}}{\varepsilon_{\gamma}}\right)^{2}+\left(\frac{\Delta \rho_{\gamma}}{\rho_{\gamma}}\right)^{2}+\left(\frac{\Delta M_{s}}{M_{s}}\right)^{2}+\left(\frac{\Delta T_{s}}{T_{s}}\right)^{2}}
$$

where $\Delta A$ is the uncertainty of the sample measurement and $\Delta N, \Delta \varepsilon_{\gamma}, \Delta \rho_{\gamma}$, $\Delta M_{s}$ and $\Delta T_{s}$ are the uncertainties of the count rate, efficiency, gamma-ray emission probability, sample weight and counting time, respectively.

\subsection{Estimation of Radiation Hazards}

To assess the radiological hazards originating from building materials, several hazard indices have been suggested by a number of investigators [2] [12]. These measures include the radium equivalent activity, the absorbed gamma dose rate in the indoor environment and the corresponding annual effective dose, the external and internal hazard indices, the alpha index (internal index), the gamma activity concentration (gamma index), annual gonadal dose equivalent, excess lifetime cancer risk, etc. In the present study, the aforementioned hazard indicators were estimated to evaluate the potential radiation risks arising from the use of the studied building materials. 
Radium equivalent activity was calculated through the relation given by Beretka and Mathew [24]

$$
R a_{\mathrm{eq}}=A_{\mathrm{Ra}}+1.43 A_{\mathrm{Th}}+0.077 A_{\mathrm{K}},
$$

where $A_{\mathrm{Ra}}, A_{\mathrm{Th}}$ and $A_{\mathrm{K}}$ are the activity concentrations of ${ }^{226} \mathrm{Ra},{ }^{232} \mathrm{Th}$ and ${ }^{40} \mathrm{~K}$ in $\mathrm{Kg} \cdot \mathrm{Bq}^{-1}$, respectively. Equation (3) is based on the estimation that 370 $\mathrm{Kg} \cdot \mathrm{Bq}^{-1}$ of ${ }^{226} \mathrm{Ra}, 259 \mathrm{Kg} \cdot \mathrm{Bq}^{-1}$ of ${ }^{232} \mathrm{Th}$ and $4810 \mathrm{Kg} \cdot \mathrm{Bq}^{-1}$ of ${ }^{40} \mathrm{~K}$ each produce an identical $\gamma$-ray dose rate.

If a radionuclide activity is known then its exposure dose rate in air at $1 \mathrm{~m}$ above the ground can be found using its conversion factor. The conversion factors of ${ }^{226} \mathrm{Ra},{ }^{232} \mathrm{Th}$ and ${ }^{40} \mathrm{~K}$ are $0.427,0.662$ and $0.043 \mathrm{nGy} \cdot \mathrm{h}^{-1}$ per $\mathrm{Bq} \cdot \mathrm{kg}^{-1}$, respectively [25]. The contribution of terrestrial gamma radiation to absorbed doses in air was thus calculated using the following formula:

$$
D\left(\mathrm{nGy} \cdot \mathrm{h}^{-1}\right)=0.427 A_{\mathrm{Ra}}+0.662 A_{\mathrm{Th}}+0.0432 A_{\mathrm{K}}
$$

The absorbed dose rate in air at $1 \mathrm{~m}$ above the ground surface does not directly provide the radiological risk to which an individual is exposed. The absorbed dose can be considered in terms of the annual effective dose equivalent from outdoor terrestrial gamma radiation which can be estimated by taking into account the conversion coefficient from absorbed dose in air to effective dose and the outdoor occupancy factor. In the present study, a dose conversion coefficient of $0.7 \mathrm{~Sv} \cdot \mathrm{Gy}^{-1}$ and an outdoor occupancy factor of 0.2 were used as recommended by UNSCEAR [25]. The annual effective dose equivalent was calculated from following equation:

$$
D_{\text {eff }}\left(\mu \mathrm{Sv} \cdot \mathrm{y}^{-1}\right)=D\left(\mathrm{nGy} \cdot \mathrm{h}^{-1}\right) \times 8760\left(\mathrm{~h} \cdot \mathrm{y}^{-1}\right) \times 0.2 \times 0.7\left(\mathrm{~Sv} \cdot \mathrm{Gy}^{-1}\right) \times 10^{-3} .
$$

The external hazard index $H_{\mathrm{ex}}$ was calculated using the model proposed by Krieger [26], assuming thick walls without windows and doors, as

$$
H_{\text {ex }}=\frac{A_{\mathrm{Ra}}}{370 \mathrm{~Bq} \cdot \mathrm{kg}^{-1}}+\frac{A_{T h}}{259 \mathrm{~Bq} \cdot \mathrm{kg}^{-1}}+\frac{A_{K}}{4810 \mathrm{~Bq} \cdot \mathrm{kg}^{-1}} .
$$

The $H_{\mathrm{ex}}$ index must be less than unity so that the annual effective dose due to radioactivity in the material will be $\leq 1.5 \mathrm{mSv} \cdot \mathrm{y}^{-1}$. In addition to $H_{\mathrm{ex}}$ index, inhaled radon and its short-lived progeny also represent a risk to the respiratory organs. Internal exposure to radon and its progeny can be quantified using the index $H_{\text {in }}$, which was estimated by the following expression [26]:

$$
H_{\text {in }}=\frac{A_{\mathrm{Ra}}}{185 \mathrm{~Bq} \cdot \mathrm{kg}^{-1}}+\frac{A_{\mathrm{Th}}}{259 \mathrm{~Bq} \cdot \mathrm{kg}^{-1}}+\frac{A_{\mathrm{K}}}{4810 \mathrm{~Bq} \cdot \mathrm{kg}^{-1}} \text {. }
$$

For the utilization of a building material to be considered safe, $H_{\text {in }}$ must be less than unity.

To limit the excess gamma radiation originating from building materials, an index, known as gamma index, is defined as a screening tool for categorizing materials used in construction. It is assumed that activity concentrations of 300 Bq. $\mathrm{kg}^{-1}$ of ${ }^{226} \mathrm{Ra}, 200 \mathrm{~Bq} \cdot \mathrm{kg}^{-1}$ of ${ }^{232} \mathrm{Th}$ and $3000 \mathrm{~Bq} \cdot \mathrm{kg}^{-1}$ of ${ }^{40} \mathrm{~K}$ each produce the same gamma dose rate. Therefore, for a typical building material, the gamma 
index can be calculated using the following equation, as recommended by the European Commission [27]:

$$
I_{\gamma}=\frac{A_{\mathrm{Ra}}}{300 \mathrm{~Bq} \cdot \mathrm{kg}^{-1}}+\frac{A_{\mathrm{Th}}}{200 \mathrm{~Bq} \cdot \mathrm{kg}^{-1}}+\frac{A_{\mathrm{K}}}{3000 \mathrm{~Bq} \cdot \mathrm{kg}^{-1}} .
$$

For a structural material, the exemption dose criterion (annual effective dose) of $0.3 \mathrm{mSv} \cdot \mathrm{y}^{-1}$ corresponds to a gamma index of $I_{\gamma} \leq 0.5$, whereas the upper dose criterion of $1 \mathrm{mSv} \cdot \mathrm{y}^{-1}$ is satisfied for $I_{\gamma} \leq 1$ [27].

Excess alpha radiation caused by the inhalation of radon liberated from building materials can be estimated using the alpha index $\left(I_{\alpha}\right)$ given in [2] [12] [14] [28] as:

$$
I_{\alpha}=\frac{A_{\mathrm{Ra}}}{200 \mathrm{~Bq} \cdot \mathrm{kg}^{-1}} .
$$

Radon exhalation from a given construction material may lead to indoor radon concentrations that exceed the recommended action level of $200 \mathrm{~Bq} \cdot \mathrm{m}^{-3}$ if the activity concentration of ${ }^{226} \mathrm{Ra}$ in the material exceeds a value of $200 \mathrm{~Bq} \cdot \mathrm{kg}^{-1}$ [2] [28]. Thus, the safe limit is defined by an alpha index of less than or equal to unity.

The annual gonadal dose equivalent and excess life-time cancer risk due to the specific activities of ${ }^{226} \mathrm{Ra},{ }^{232} \mathrm{Th}$ and ${ }^{40} \mathrm{~K}$ were, respectively, calculated using the following formulae:

$$
A G D E\left(\mu \mathrm{Sv} \cdot \mathrm{y}^{-1}\right)=3.09 A_{\mathrm{Ra}}+4.18 A_{\mathrm{Th}}+0.314 A_{\mathrm{K}} .
$$

and

$$
E L C R=D_{\text {eff }} \times D L \times R F .
$$

Here, $D L$ (= 70 years) is the duration of life and $R F$ is a risk factor in $S v^{-1}$ i.e. fatal cancer risk per Sievert. For stochastic effects, ICRP 60 [29] uses $R F=0.05$ for the public.

\section{Results and Discussion}

\subsection{Activity Concentrations}

The measured dry weight activity concentrations of the main gamma emitting radionuclides of the ${ }^{226} \mathrm{Ra}$ series, ${ }^{232} \mathrm{Th}$ series and ${ }^{40} \mathrm{~K}$ in 5 different kinds of building-material samples are reported in Table 1 . The activities of the radionuclides are given in $\mathrm{Bq} \cdot \mathrm{kg}^{-1}$ and the \pm values are due to the $1 \sigma$ variation of counting uncertainties. The mean specific activities are compared in Figure 1. As can be seen in Table 1, the largest values for the specific activity of ${ }^{226} \mathrm{Ra}$ and ${ }^{232} \mathrm{Th}$ and ${ }^{40} \mathrm{~K}$ are $80.1 \pm 2.6,59.0 \pm 5.3$ and $803 \pm 17 \mathrm{~Bq} \cdot \mathrm{kg}^{-1}$, respectively, while the lowest values of the specific activity of the same radionuclides are $7.9 \pm 4.6$, $4.6 \pm 3.8$ and $138 \pm 12 \mathrm{~Bq} \cdot \mathrm{kg}^{-1}$, respectively. The mean specific radioactivity in the 5 different building materials shown in Figure 1 varies from $11.7 \pm 5.4$ $\mathrm{Bq} \cdot \mathrm{kg}^{-1}$ (for stone) to $38.1 \pm 9.9 \mathrm{~Bq} \cdot \mathrm{kg}^{-1}$ (for tile), $14.3 \pm 6.9 \mathrm{~Bq} \cdot \mathrm{kg}^{-1}$ (for stone) to $30.6 \pm 8.1 \mathrm{~Bq} \cdot \mathrm{kg}^{-1}$ (for tile) and $240 \pm 4 \mathrm{~Bq} \cdot \mathrm{kg}^{-1}$ (for marble) to $418 \pm 10 \mathrm{~Bq} \cdot \mathrm{kg}^{-1}$ 
Table 1. Radioactivity concentrations of ${ }^{226} \mathrm{Ra}$ series, ${ }^{232} \mathrm{Th}$ series and ${ }^{40} \mathrm{~K}$ (in Bq$\cdot \mathrm{kg}^{-1} \pm 1 \sigma$ ) in 24 studied building materials.

\begin{tabular}{|c|c|c|c|c|c|c|c|c|c|}
\hline \multirow[b]{2}{*}{$\begin{array}{c}\text { Sample } \\
\text { Type }\end{array}$} & \multicolumn{4}{|c|}{${ }^{226} \mathrm{Ra}$ series } & \multicolumn{4}{|c|}{${ }^{232} \mathrm{Th}$ series } & \multirow{2}{*}{$\begin{array}{c}{ }^{40} \mathrm{~K} \\
(1461 \mathrm{keV})\end{array}$} \\
\hline & $\begin{array}{c}{ }^{214} \mathrm{~Pb} \\
(295 \mathrm{keV})\end{array}$ & $\begin{array}{c}{ }^{214} \mathrm{~Pb} \\
(352 \mathrm{keV})\end{array}$ & $\begin{array}{c}{ }^{214} \mathrm{Bi} \\
(609 \mathrm{keV})\end{array}$ & $\begin{array}{c}{ }^{214} \mathrm{Bi} \\
(1120 \mathrm{keV})\end{array}$ & $\begin{array}{c}{ }^{212} \mathrm{~Pb} \\
(239 \mathrm{keV})\end{array}$ & $\begin{array}{c}{ }^{208} \mathrm{Tl} \\
(583 \mathrm{keV})\end{array}$ & $\begin{array}{c}{ }^{228} \mathrm{Ac} \\
(911 \mathrm{keV})\end{array}$ & $\begin{array}{c}{ }^{228} \mathrm{Ac} \\
(969 \mathrm{keV})\end{array}$ & \\
\hline \multicolumn{10}{|l|}{$\underline{\text { Stone }}$} \\
\hline ST1 & $5.78 \pm 1.99$ & $4.75 \pm 1.35$ & $13.17 \pm 1.72$ & $28.04 \pm 3.03$ & $11.00 \pm 2.16$ & $4.89 \pm 0.74$ & $25.25 \pm 2.59$ & $16.34 \pm 2.93$ & $803.07 \pm 16.63$ \\
\hline ST2 & $9.03 \pm 1.37$ & $14.21 \pm 2.08$ & $13.39 \pm 1.26$ & 0.00 & $9.43 \pm 1.40$ & $4.45 \pm 0.21$ & $18.81 \pm 1.70$ & $7.90 \pm 2.07$ & $257.16 \pm 11.37$ \\
\hline ST3 & $6.16 \pm 1.25$ & $10.53 \pm 1.78$ & $10.82 \pm 1.72$ & $13.03 \pm 0.51$ & $9.39 \pm 0.99$ & $4.53 \pm 0.72$ & $17.65 \pm 1.63$ & $16.56 \pm 0.85$ & $295.14 \pm 9.67$ \\
\hline ST4 & $12.34 \pm 1.87$ & $19.27 \pm 2.70$ & $2.43 \pm 0.61$ & $8.29 \pm 1.64$ & $15.91 \pm 2.04$ & $15.12 \pm 0.62$ & $19.61 \pm 0.74$ & $11.97 \pm 1.34$ & $503.70 \pm 6.11$ \\
\hline ST5 & $2.39 \pm 0.62$ & $22.24 \pm 1.96$ & $4.98 \pm 1.11$ & $5.30 \pm 1.26$ & $11.90 \pm 1.69$ & $1.86 \pm 0.36$ & $29.28 \pm 2.22$ & $10.48 \pm 1.34$ & $230.33 \pm 6.45$ \\
\hline Range & \multicolumn{4}{|c|}{$7.9 \pm 4.6$ to $15.8 \pm 4.9$} & \multicolumn{4}{|c|}{$12.0 \pm 5.9$ to $17.4 \pm 10.7$} & $230 \pm 6$ to $803 \pm 17$ \\
\hline \multicolumn{10}{|l|}{$\underline{\text { Sand }}$} \\
\hline SA1 & $14.44 \pm 2.87$ & $10.72 \pm 1.60$ & $9.73 \pm 1.06$ & $25.66 \pm 4.17$ & $1.64 \pm 1.87$ & $2.41 \pm 0.46$ & $10.08 \pm 1.41$ & $4.24 \pm 1.34$ & $137.80 \pm 12.22$ \\
\hline SA2 & $11.35 \pm 2.87$ & $11.36 \pm 1.60$ & $9.85 \pm 1.06$ & $25.48 \pm 4.17$ & $13.97 \pm 1.87$ & $7.52 \pm 0.46$ & $26.80 \pm 1.41$ & $9.79 \pm 1.34$ & $497.29 \pm 12.22$ \\
\hline SA3 & $3.02 \pm 0.50$ & $5.73 \pm 0.80$ & $7.91 \pm 0.61$ & $4.47 \pm 0.76$ & $5.84 \pm 1.17$ & $1.64 \pm 0.18$ & $11.93 \pm 0.89$ & $17.16 \pm 1.83$ & $153.46 \pm 4.92$ \\
\hline SA4 & $24.12 \pm 7.48$ & $13.55 \pm 3.07$ & $16.50 \pm 1.67$ & $12.64 \pm 1.14$ & $23.22 \pm 4.55$ & $8.57 \pm 0.95$ & $31.17 \pm 1.63$ & $31.40 \pm 3.05$ & $333.29 \pm 5.09$ \\
\hline SA5 & $7.85 \pm 4.73$ & $14.60 \pm 3.19$ & $16.26 \pm 4.30$ & $24.39 \pm 2.40$ & $28.88 \pm 4.79$ & $9.74 \pm 0.95$ & $27.55 \pm 1.93$ & $22.12 \pm 2.68$ & $298.55 \pm 4.92$ \\
\hline Range & \multicolumn{4}{|c|}{$11.6 \pm 2.5$ to $18.1 \pm 5.5$} & \multicolumn{4}{|c|}{$4.6 \pm 3.8$ to $23.6 \pm 10.7$} & $138 \pm 12$ to $497 \pm 12$ \\
\hline \multicolumn{10}{|l|}{ Cement } \\
\hline CE1 & $7.50 \pm 1.87$ & $20.10 \pm 3.31$ & $33.60 \pm 2.63$ & $12.90 \pm 1.64$ & $27.45 \pm 3.21$ & $1.56 \pm 0.62$ & $3.44 \pm 0.74$ & $31.35 \pm 1.34$ & $271.20 \pm 6.11$ \\
\hline CE2 & $15.63 \pm 1.87$ & $19.14 \pm 1.96$ & $10.37 \pm 0.66$ & $42.54 \pm 5.18$ & $11.30 \pm 1.87$ & $2.25 \pm 0.44$ & $22.03 \pm 1.41$ & $22.03 \pm 1.46$ & $212.61 \pm 8.32$ \\
\hline CE3 & $12.88 \pm 1.74$ & $14.21 \pm 2.03$ & $20.75 \pm 1.87$ & $23.84 \pm 3.41$ & $15.16 \pm 1.23$ & $7.79 \pm 0.46$ & $28.15 \pm 2.59$ & $31.58 \pm 2.80$ & $259.87 \pm 8.32$ \\
\hline $\mathrm{CE} 4$ & $43.12 \pm 3.86$ & $25.08 \pm 2.33$ & $33.33 \pm 2.12$ & $46.12 \pm 3.92$ & $16.39 \pm 0.99$ & $11.59 \pm 0.51$ & $30.83 \pm 2.30$ & $33.18 \pm 3.20$ & $426.23 \pm 10.01$ \\
\hline CE5 & $26.91 \pm 1.62$ & $25.75 \pm 2.52$ & $31.72 \pm 3.23$ & $25.59 \pm 1.39$ & $21.34 \pm 2.80$ & $8.48 \pm 0.10$ & $25.51 \pm 1.41$ & $38.51 \pm 2.80$ & $319.94 \pm 11.54$ \\
\hline Range & \multicolumn{4}{|c|}{$15.0 \pm 4.4$ to $33.8 \pm 9.0$} & \multicolumn{4}{|c|}{$14.4 \pm 8.6$ to $23.5 \pm 12.4$} & $213 \pm 8$ to $426 \pm 10$ \\
\hline \multicolumn{10}{|c|}{ Ceramic Tile } \\
\hline CT1 & $29.04 \pm 4.49$ & $13.12 \pm 3.93$ & $20.57 \pm 1.52$ & $9.46 \pm 2.15$ & $23.75 \pm 3.68$ & $0.94 \pm 0.51$ & 0.00 & $33.48 \pm 3.78$ & $500.39 \pm 7.47$ \\
\hline $\mathrm{CT} 2$ & $25.64 \pm 4.49$ & $6.97 \pm 0.61$ & $8.99 \pm 1.57$ & $12.34 \pm 2.27$ & $11.02 \pm 1.58$ & $3.65 \pm 0.82$ & $12.94 \pm 1.70$ & $16.47 \pm 2.80$ & $207.43 \pm 4.41$ \\
\hline CT3 & $80.90 \pm 9.10$ & $77.10 \pm 4.24$ & $82.18 \pm 2.53$ & $94.04 \pm 3.16$ & $66.00 \pm 5.66$ & $21.18 \pm 1.13$ & $49.12 \pm 2.44$ & $58.66 \pm 3.66$ & $517.80 \pm 5.94$ \\
\hline CT4 & $41.74 \pm 7.35$ & $12.87 \pm 3.19$ & $18.64 \pm 1.77$ & $21.29 \pm 2.53$ & $16.65 \pm 4.38$ & $4.38 \pm 0.82$ & $12.65 \pm 1.78$ & $7.84 \pm 2.56$ & $223.73 \pm 3.90$ \\
\hline CT5 & $26.93 \pm 4.49$ & $28.03 \pm 3.50$ & $32.22 \pm 1.92$ & $37.63 \pm 2.53$ & $30.19 \pm 5.14$ & $13.72 \pm 0.95$ & $39.86 \pm 1.78$ & $27.41 \pm 3.53$ & $319.08 \pm 5.09$ \\
\hline CT6 & $45.01 \pm 8.72$ & $52.59 \pm 3.80$ & $58.54 \pm 2.17$ & $50.65 \pm 3.03$ & $60.45 \pm 5.25$ & $17.91 \pm 1.08$ & $53.03 \pm 2.15$ & $63.40 \pm 3.29$ & $475.28 \pm 5.09$ \\
\hline CT7 & $25.16 \pm 9.72$ & $35.65 \pm 7.92$ & $67.11 \pm 3.74$ & $28.88 \pm 2.65$ & $34.83 \pm 5.60$ & 0.00 & $35.25 \pm 2.67$ & $36.02 \pm 4.14$ & $655.43 \pm 8.32$ \\
\hline Range & \multicolumn{4}{|c|}{$17.3 \pm 11.8$ to $80.1 \pm 2.6$} & \multicolumn{4}{|c|}{$10.4 \pm 5.4$ to $59.0 \pm 5.3$} & $207 \pm 4$ to $655 \pm 8$ \\
\hline \multicolumn{10}{|l|}{ Marble } \\
\hline IM1 & $33.61 \pm 2.87$ & $14.31 \pm 2.52$ & $16.10 \pm 1.67$ & $16.17 \pm 2.15$ & $24.44 \pm 1.28$ & $3.07 \pm 0.38$ & $17.30 \pm 1.78$ & $15.59 \pm 2.68$ & $236.61 \pm 4.41$ \\
\hline IM2 & $14.93 \pm 7.35$ & $12.01 \pm 3.13$ & $13.55 \pm 1.67$ & $25.20 \pm 2.27$ & $9.67 \pm 4.09$ & $5.32 \pm 0.85$ & $15.79 \pm 1.70$ & $21.97 \pm 2.44$ & $242.98 \pm 4.07$ \\
\hline Range & \multicolumn{4}{|c|}{$13.5 \pm 1.5$ to $21.3 \pm 10.7$} & \multicolumn{4}{|c|}{$15.8 \pm 6.2$ to $19.1 \pm 4.5$} & $237 \pm 4$ to $243 \pm 4$ \\
\hline
\end{tabular}




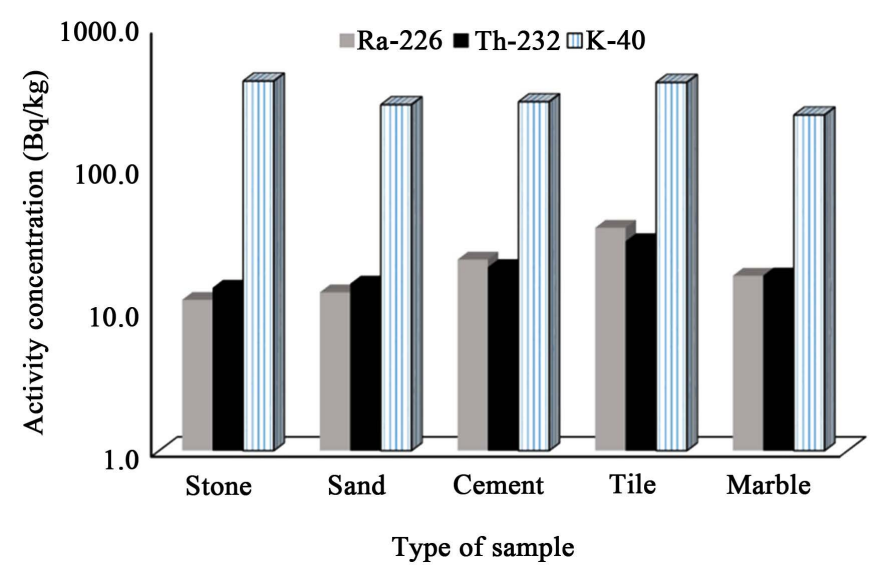

Figure 1. (Colour online) Comparison of mean specific activities of ${ }^{226} \mathrm{Ra},{ }^{232} \mathrm{Th}$ and ${ }^{40} \mathrm{~K}$ measured in 5 different types of studied building materials.

(for stone) of ${ }^{226} \mathrm{Ra},{ }^{232} \mathrm{Th}$ and ${ }^{40} \mathrm{~K}$, respectively. All these mean values are comparable to the corresponding world average values of 40,40 and $400 \mathrm{~Bq} \cdot \mathrm{kg}^{-1}$ [1], respectively for ${ }^{226} \mathrm{Ra},{ }^{232} \mathrm{Th}$ and ${ }^{40} \mathrm{~K}$. However, the levels of ${ }^{226} \mathrm{Ra}$ in three tile-samples (CT3, CT6 and CT7), ${ }^{232} \mathrm{Th}$ in two tile-samples (СT3 and CT6), and ${ }^{40} \mathrm{~K}$ in one stone sample (ST1) and one tile sample (CT7) slightly overestimate the world average.

The comparison of the present results for the ${ }^{226} \mathrm{Ra},{ }^{232} \mathrm{Th}$ and ${ }^{40} \mathrm{~K}$ concentrations with the reported data for selected building materials available in literature are depicted in Table 2. The activities for each material and radioisotope show a wide range of values. In general, the mean specific activities of the studied building materials are comparable to those from other countries. However, the ${ }^{226} \mathrm{Ra}$ concentrations in marble samples are much lower in Turkey [3] than the present measurements. For ${ }^{232} \mathrm{Th}$ concentrations, the lower values than the present results are found in Italy [30] for stone samples and in Turkey [3] for marble samples. In case of ${ }^{40} \mathrm{~K}$ concentrations for stone samples the present result is higher than those reported by other countries. This variation in activity concentrations may be due to their radioactive mineral content and the geographical origins of the raw materials.

It is worth mentioning that for all studied building materials, the average measured radium activities were found to be greater than the thorium activities. The possible reason for the higher values of uranium is that the Padma river flows, as the Ganges, through Bihar in India, where there is a uranium mine. The Brahmaputra, Surma and Kushiyara rivers flow through Assam in India, where there is a uranium deposit. Thus, it is likely that the traces of uranium and its decay products are carried with the water flow through these rivers, causing the uranium level to be somewhat higher in Bangladesh.

\subsection{Hazard Indices}

Various hazard indices associated with the radioactivity of the studied building materials and evaluated by using Equations (3)-(11) are presented in Table 3. 
M. A. Khatun et al.

Table 2. Comparison of activity concentrations $\left(\mathrm{Bq} \cdot \mathrm{kg}^{-1}\right)$ of different building materials from different parts of the world.

\begin{tabular}{|c|c|c|c|c|c|}
\hline Region & Sample Type & ${ }^{226} \mathrm{Ra}$ series & ${ }^{232} \mathrm{Th}$ series & ${ }^{40} \mathrm{~K}$ & Reference \\
\hline Algeria & Stone & $16 \pm 3$ & $13 \pm 2$ & $36 \pm 3$ & [11] \\
\hline Italy & Stone & 11 & $2.0 \pm 2.0$ & $22 \pm 3$ & [30] \\
\hline Egypt & Stone & $27.8 \pm 1.4$ & $46.6 \pm 2.3$ & $66 \pm 3.3$ & [31] \\
\hline KSA & Stone & $28.6 \pm 4.2$ & $49.2 \pm 2.5$ & $66 \pm 3.6$ & [17] \\
\hline India & Stone & $46 \pm 8$ & $57 \pm 12$ & $432 \pm 64$ & [12] \\
\hline Pakistan & Lime Stone & $28.4 \pm 8.7$ & $11.3 \pm 1.7$ & $63.1 \pm 17.3$ & [32] \\
\hline Present study & Stone & $8-16$ & $12-18$ & $230-803$ & \\
\hline Turkey & Sand & $38.8 \pm 10.0$ & $29.5 \pm 11.3$ & $471 \pm 101$ & [14] \\
\hline Algeria & Sand & $12 \pm 1$ & $7 \pm 1$ & $74 \pm 7$ & [11] \\
\hline China & Sand & $40.7 \pm 4.3$ & $21.5 \pm 5.6$ & $303 \pm 3$ & [10] \\
\hline Greece & Sand & $18 \pm 7$ & $17 \pm 10$ & $367 \pm 204$ & [15] \\
\hline Qatar & Sand & $13.2 \pm 0.3$ & $3.3 \pm 0.1$ & $226 \pm 6$ & [33] \\
\hline Cuba & Sand & $17 \pm 4$ & $16 \pm 6$ & $208 \pm 104$ & [34] \\
\hline Present study & Sand & $12-18$ & $5-24$ & $138-497$ & \\
\hline Turkey & Cement & $49.8 \pm 5.8$ & $17.3 \pm 2.2$ & $246 \pm 20$ & [14] \\
\hline Greece & Cement & $20 \pm 5$ & $13 \pm 3$ & $247 \pm 68$ & [15] \\
\hline Algeria & Cement & $41 \pm 7$ & $27 \pm 3$ & $422 \pm 3$ & [11] \\
\hline Qatar & Cement & $23.4 \pm 0.6$ & $12.2 \pm 0.2$ & $159 \pm 4$ & [33] \\
\hline Nigeria & Cement & 43.8 & 21.5 & 72 & [19] \\
\hline Cuba & Cement & $23 \pm 7$ & $11 \pm 3$ & $467 \pm 85$ & [34] \\
\hline China & Cement & 56.5 & 36.5 & 173.2 & [10] \\
\hline South Korea & Cement & $34.5 \pm 1.7$ & $19.4 \pm 1.5$ & $241 \pm 7$ & [35] \\
\hline India & Cement & $54 \pm 13$ & $65 \pm 10$ & $440 \pm 91$ & [12] \\
\hline Pakistan & Cement & $34.2 \pm 11.9$ & $29.1 \pm 3.6$ & $295.1 \pm 66.9$ & [32] \\
\hline Present study & Cement & $15-34$ & $14-24$ & $213-426$ & \\
\hline South Korea & Tile & $44-82$ & $34-96$ & $310-1019$ & [35] \\
\hline Greece & Ceramics & $25-174$ & $29-47$ & $411-786$ & [13] \\
\hline Egypt & Ceramics & $61-118$ & $55-98$ & $730-1050$ & [36] \\
\hline India & Ceramics & 28 & 64 & 24 & [37] \\
\hline China & Ceramic tile & 73 & 62 & 480 & [4] \\
\hline Turkey & Ceramic tile & 96 & $53-69$ & $290-579$ & [3] \\
\hline Italy & Porous Tile & $53 \pm 15$ & $53 \pm 12$ & $411-996$ & [16] \\
\hline Present study & Tile & $17-80$ & $10-59$ & $207-655$ & \\
\hline Algeria & Marble chip & $23 \pm 2$ & $18 \pm 2$ & $310 \pm 3$ & [11] \\
\hline Egypt & Marble & $205 \pm 83$ & 72 & $870 \pm 3.9$ & [18] \\
\hline Turkey & Marble & $5.4 \pm 4.8$ & $4.9 \pm 3.8$ & $49.7 \pm 19$ & [3] \\
\hline Present study & Marble & $14-21$ & $16-19$ & $237-243$ & \\
\hline
\end{tabular}


Table 3. Calculated various hazard indices associated with the radioactivity of the studied building materials.

\begin{tabular}{|c|c|c|c|c|c|c|c|c|c|}
\hline Sample & $\begin{array}{c}\mathrm{Ra}_{\mathrm{eq}} \\
(\mathrm{Bq} / \mathrm{kg})\end{array}$ & $\begin{array}{c}\mathrm{D} \\
(\mathrm{nGy} / \mathrm{h})\end{array}$ & $\begin{array}{c}D_{\text {eff }} \\
(\mu \mathrm{Sv} / \mathrm{y})\end{array}$ & $\mathrm{H}_{\mathrm{ex}}$ & $\mathrm{H}_{\mathrm{in}}$ & $\mathrm{I}_{\gamma}$ & $\mathrm{I}_{\alpha}$ & $\begin{array}{l}\text { AGDE } \\
(\mu \mathrm{Sv} / \mathrm{y})\end{array}$ & $\begin{array}{l}\text { ELCR } \\
\times 10^{-4}\end{array}$ \\
\hline \multicolumn{10}{|l|}{$\underline{\text { Stone }}$} \\
\hline ST1 & 90.3 & 45.8 & 56 & 0.24 & 0.27 & 0.37 & 0.04 & 337 & 11.8 \\
\hline ST2 & 49.2 & 23.6 & 29 & 0.13 & 0.17 & 0.19 & 0.06 & 169 & 5.9 \\
\hline ST3 & 49.1 & 23.8 & 29 & 0.13 & 0.16 & 0.19 & 0.05 & 171 & 6.0 \\
\hline ST4 & 77.0 & 37.8 & 46 & 0.21 & 0.25 & 0.30 & 0.08 & 272 & 9.5 \\
\hline ST5 & 56.2 & 26.4 & 33 & 0.15 & 0.19 & 0.21 & 0.07 & 187 & 6.6 \\
\hline Average & $64.4 \pm 16.5$ & $31.5 \pm 8.9$ & $39 \pm 11$ & $0.17 \pm 0.04$ & $0.21 \pm 0.04$ & $0.25 \pm 0.07$ & $0.06 \pm 0.01$ & $227 \pm 67$ & $8.0 \pm 2.3$ \\
\hline Range & $49-90$ & $24-46$ & $29-56$ & $0.13-0.24$ & $0.16-0.27$ & $0.19-0.37$ & $0.04-0.08$ & $169-337$ & $6.0-12$ \\
\hline \multicolumn{10}{|l|}{$\underline{\text { Sand }}$} \\
\hline SA1 & 71.3 & 35.1 & 43 & 0.19 & 0.23 & 0.28 & 0.06 & 255 & 8.9 \\
\hline SA2 & 28.8 & 13.9 & 17 & 0.08 & 0.11 & 0.11 & 0.06 & 98 & 3.5 \\
\hline SA3 & 40.1 & 18.8 & 23 & 0.11 & 0.14 & 0.15 & 0.06 & 133 & 4.7 \\
\hline SA4 & 77.5 & 36.5 & 45 & 0.21 & 0.26 & 0.29 & 0.09 & 259 & 9.1 \\
\hline SA5 & 67.5 & 31.7 & 39 & 0.18 & 0.22 & 0.25 & 0.06 & 226 & 7.9 \\
\hline Average & $57.0 \pm 19.1$ & $27.2 \pm 9.1$ & $33 \pm 11$ & $0.15 \pm 0.05$ & $0.19 \pm 0.06$ & $0.22 \pm 0.07$ & $0.07 \pm 0.01$ & $194 \pm 66$ & $6.8 \pm 2.3$ \\
\hline Range & $29-78$ & $14-37$ & $17-45$ & $0.08-0.21$ & $0.11-0.26$ & $0.11-0.29$ & $0.06-0.09$ & $98-259$ & $3.5-9.1$ \\
\hline \multicolumn{10}{|l|}{ Cement } \\
\hline CE1 & 83.3 & 38.5 & 47 & 0.23 & 0.28 & 0.31 & 0.10 & 208 & 7.3 \\
\hline CE2 & 57.8 & 27.0 & 33 & 0.16 & 0.20 & 0.21 & 0.08 & 190 & 6.7 \\
\hline CE3 & 65.5 & 30.7 & 38 & 0.18 & 0.22 & 0.24 & 0.08 & 217 & 7.6 \\
\hline CE4 & 99.6 & 47.3 & 58 & 0.27 & 0.36 & 0.37 & 0.17 & 335 & 1.2 \\
\hline CE5 & 86.3 & 40.5 & 50 & 0.23 & 0.31 & 0.32 & 0.14 & 285 & 8.0 \\
\hline Average & $78.5 \pm 15.0$ & $36.8 \pm 7.2$ & $45 \pm 9$ & $0.21 \pm 0.04$ & $0.27 \pm 0.06$ & $0.29 \pm 0.06$ & $0.11 \pm 0.04$ & $247 \pm 55$ & $6.2 \pm 2.5$ \\
\hline Range & $58-100$ & $27-47$ & $33-58$ & $0.16-0.27$ & $0.20-0.36$ & $0.21-0.37$ & $0.08-0.17$ & $190-335$ & $1.2-8.0$ \\
\hline \multicolumn{10}{|c|}{$\underline{\text { Ceramic Tile }}$} \\
\hline CT1 & 86.7 & 42.0 & 52 & 0.23 & 0.29 & 0.33 & 0.10 & 301 & 10.6 \\
\hline CT2 & 52.6 & 24.8 & 31 & 0.14 & 0.19 & 0.19 & 0.09 & 175 & 6.1 \\
\hline CT3 & 189.6 & 88.0 & 108 & 0.51 & 0.73 & 0.68 & 0.40 & 614 & 21.5 \\
\hline CT4 & 56.5 & 26.9 & 33 & 0.15 & 0.22 & 0.21 & 0.12 & 189 & 6.6 \\
\hline CT5 & 93.4 & 43.5 & 53 & 0.25 & 0.33 & 0.34 & 0.15 & 306 & 10.7 \\
\hline CT6 & 169.9 & 77.8 & 96 & 0.46 & 0.60 & 0.61 & 0.26 & 544 & 19.0 \\
\hline CT7 & 143.7 & 68.4 & 84 & 0.39 & 0.50 & 0.54 & 0.21 & 485 & 17.0 \\
\hline Average & $113.2 \pm 50.7$ & $53.1 \pm 23.2$ & $65 \pm 28$ & $0.30 \pm 0.14$ & $0.41 \pm 0.19$ & $0.48 \pm 0.19$ & $0.19 \pm 0.10$ & $373 \pm 162$ & $13.1 \pm 5.7$ \\
\hline Range & $53-190$ & $25-88$ & $31-108$ & $0.14-0.51$ & $0.19-0.73$ & $0.19-0.68$ & $0.09-0.40$ & $175-614$ & $6.1-21.5$ \\
\hline \multicolumn{10}{|l|}{ Marble } \\
\hline IM1 & 66.9 & 31.3 & 38 & 0.18 & 0.24 & 0.25 & 0.11 & 220 & 7.7 \\
\hline IM2 & 54.8 & 25.9 & 32 & 0.15 & 0.18 & 0.21 & 0.07 & 184 & 6.4 \\
\hline Average & $60.9 \pm 6.1$ & $28.6 \pm 2.7$ & $35 \pm 3$ & $0.17 \pm 0.02$ & $0.21 \pm 0.03$ & $0.23 \pm 0.02$ & $0.09 \pm 0.02$ & $202 \pm 18$ & $7.1 \pm 0.7$ \\
\hline Range & $55-67$ & $26-31$ & $32-38$ & $0.15-0.18$ & $0.18-0.24$ & $0.21-0.25$ & $0.07-0.11$ & $184-220$ & $6.4-7.7$ \\
\hline
\end{tabular}


Generally, the distribution of ${ }^{226} \mathrm{Ra},{ }^{232} \mathrm{Th}$ and ${ }^{40} \mathrm{~K}$ in environmental samples including construction materials are not uniform. In order to overcome the non-uniformity of the radionuclides, a common index called "radium equivalent activity $\left(R a_{\text {eq }}\right)$ " is used to obtain the activity and also to assess the radiological hazard caused by the building materials. As shown in Table 3, the values of $R a_{\text {eq }}$ varie between 29 and $190 \mathrm{~Bq} \cdot \mathrm{kg}^{-1}$ with the mean $( \pm \mathrm{SD})$ values from $57.0 \pm 19.1$ $\mathrm{Bq} \cdot \mathrm{kg}^{-1}$ (for sand) to $113.2 \pm 50.7 \mathrm{~Bq} \cdot \mathrm{kg}^{-1}$ (for ceramic tile). It is evident that all the $R a_{\text {eq }}$ values in the present work are lower than the upper recommended value of $370 \mathrm{~Bq} \cdot \mathrm{kg}^{-1}$ [24]. On comparing with other countries, it is observed that the $R a_{\text {eq }}$ values of this work are lower than that of $436 \pm 199 \mathrm{~Bq} \cdot \mathrm{kg}^{-1}$ for marble and $267 \mathrm{~Bq} \cdot \mathrm{kg}^{-1}$ for ceramic in Egypt [18] [36]; $183 \pm 39 \mathrm{~Bq} \cdot \mathrm{kg}^{-1}$ for tile in Italy [16]; $121 \mathrm{~Bq} \cdot \mathrm{kg}^{-1}$ for tile in India [37]; and $112 \pm 8.2 \mathrm{~Bq} \cdot \mathrm{kg}^{-1}$ for cement and $73.0 \pm 4.1$ $\mathrm{Bq} \cdot \mathrm{kg}^{-1}$ for marble in Algeria [11]. However, the present results are higher than that of $37.0 \pm 4.7 \mathrm{~Bq} \cdot \mathrm{kg}^{-1}$ for stone and $28.0 \pm 7.1 \mathrm{~Bq} \cdot \mathrm{kg}^{-1}$ for sand in Algeria [11]; and $9.8 \pm 3.4 \mathrm{~Bq} \cdot \mathrm{kg}^{-1}$ for marble in Turkey [3].

The greatest part of the gamma radiation comes from terrestrial radionuclides. There is a direct connection between terrestrial gamma radiation and radionuclide concentrations. The calculated outdoor (terrestrial) gamma dose rates, $D$ in air $1 \mathrm{~m}$ above ground range between 24 and $88 \mathrm{nGy} \cdot \mathrm{h}^{-1}$. All of the present $D$ values, except for three tile samples (CT3, CT6, CT7), are lower than the international recommended limit of $57 \mathrm{nGy} \cdot \mathrm{h}^{-1}$ [1]. On the other hand, the mean $D$ values range from $27.2 \pm 9.1 \mathrm{nGy} \cdot \mathrm{h}^{-1}$ (for sand) to $53.1 \pm 23.2 \mathrm{nGy} \cdot \mathrm{h}^{-1}$ (for tile) and these values are below the world average. The annual effective dose equivalents, $D_{\text {eff }}$ calculated from the outdoor terrestrial gamma radiation for the studied 24 building materials are listed in Table 3. The values of $D_{\text {eff }}$ for the studied samples, except again for three tile samples (CT3, CT6, CT7), are clearly smaller than the world average value of $70 \mathrm{~Sv} \cdot \mathrm{y}^{-1}[1]$.

Since $\gamma$-rays emitted from building materials can easily travel long distances within the surrounding environment, human beings may continuously exposed by gamma radiation and adverse health effects may occurred via extended period of exposure. Thus, the representative gamma-index $\left(I_{\gamma}\right)$ finds great significance to understand the health hazards from gamma-radiation exposures. Furthermore, external hazard index $\left(H_{\mathrm{ex}}\right)$ is often used to characterize the building materials to set up a limiting value on the acceptable equivalent dose or to limit the external $\gamma$-radiation dose. It is observed in Table 3 that the mean values of $I_{\gamma}$ are below the criterion of 0.5 corresponding to an annual effective dose $0.3 \mathrm{mSv}$ except for the ceramic-tile samples CT3, CT6 and CT7. The mean values of $I_{\gamma}$ for these samples $(0.68,0.61$ and 0.54 respectively) are below the criterion of unity corresponding to an annual effective dose of $1 \mathrm{mSv}$. All the present $H_{\mathrm{ex}}$ values are lower than the critical value of unity.

Some building materials such as fly-ash and cement can easily be inhaled by people and then the $\alpha$ and $\beta$ emitters can easily be attached to the living cell of the respiratory organs, causes the cell damage as well as create cancer. For these reasons internal hazard index $\left(H_{\text {in }}\right)$ and alpha index $\left(I_{\alpha}\right)$ are often used 
to characterized building materials. As seen in Table 3, the present mean values of $I_{\alpha}$ and $H_{\text {in }}$ range from $0.06 \pm 0.01$ (for stone) to $0.19 \pm 0.10$ (for ceramic tile) and $0.21 \pm 0.03$ (for marble) to $0.41 \pm 0.19$ (for ceramic tile), respectively, and all these values are below the critical value of unity.

The activity bone marrow and the bone surface cells are considered as the organs of interest [25]. Two hazard indices, annual gonadal dose equivalent (AGDE) and associated excess lifetime cancer risk (ELCR), are significant to assess the potential radiation hazard due to the specific activities of ${ }^{226} \mathrm{Ra},{ }^{232} \mathrm{Th}$ and ${ }^{40} \mathrm{~K}$. It is evident from Table 3 that the mean values of AGDE and ELCR calculated in the present study range from $194 \pm 66$ to $373 \pm 162 \mu \mathrm{Sv}^{-1} \mathrm{y}^{-1}$ and $(6.2$ $\pm 2.5) \times 10^{-4}$ to $(13.1 \pm 5.7) \times 10^{-4}$, respectively. On comparing the AGDE values from some other countries, it is observed that value of this work is lower than the calculated values of $550.5 \mu \mathrm{Sv} \cdot \mathrm{y}^{-1}$ in Firtna Valley (Rize, Turkey) [38] and $2398 \mu \mathrm{Sv} \cdot \mathrm{y}^{-1}$ in Eastern Desert of Egypt [39]; and is comparable to the world-average value of $300 \mu \mathrm{Sv} \cdot \mathrm{y}^{-1}$.

\section{Conclusion}

A total of 24 samples of 5 different kinds natural and manufactured building materials used for dwelling in Bangladesh were analyzed for ${ }^{226} \mathrm{Ra},{ }^{232} \mathrm{Th}$ and ${ }^{40} \mathrm{~K}$ employing gamma spectrometry system equipped with a high-resolution HPGe. The mean concentrations of the above mentioned radionuclides measured in this study were found to be within the typical global range and also compared suitably with the literature values. The measured activity concentrations were also used to estimate several radiological parameters that served to qualify and quantify the radiological hazard associated with the studied building materials. The radium-equivalent activities for the studied building materials were also below the criterion limit of $\gamma$-radiation dose of $370 \mathrm{~Bq} \cdot \mathrm{kg}^{-1}$. The values of internal and external hazard indices for all investigated samples were found to below the unity. The mean annual effective dose equivalents calculated from the outdoor terrestrial gamma radiation for structural building materials were seen to be within the recommended safety limit. The use of these materials in construction of dwellings may, therefore, be considered as safe for inhabitants. As a conclusion, the data reported herein can be used to enlarge the database on natural radioactivity in building materials commonly used in Bangladesh and to support technical aspects in hazard exposure reduction.

\section{Acknowledgements}

This study has been carried out within the framework of research project supported by the Faculty of Science, Rajshahi University. The authors wish to thank Prof. Dr. M. Aminul Islam for his kind help.

\section{Conflicts of Interest}

The authors declare no conflicts of interest regarding the publication of this paper. 


\section{References}

[1] United Nations (2000) Sources, Effects and Risks of Ionizing Radiation. Report to the General Assembly on the Effects of Atomic Radiation, United Nations Scientific Committee on the Effects of Atomic Radiation, New York.

[2] Righi, S. and Bruzzi, L. (2006) Natural Radioactivity and Radon Exhalation in Building Materials Used in Italian Dwellings. Journal of Environmental Radioactivity, 88, 158-170. https://doi.org/10.1016/j.jenvrad.2006.01.009

[3] Turhan, S., Baykan, U.N. and Sen, K. (2008) Measurement of the Natural Radioactivity in Building Materials Used in Ankara and Assessment of External Doses. Journal of Radiological Protection, 28, 83-91. https://doi.org/10.1088/0952-4746/28/1/005

[4] Lu, X.W. (2004) Radioactivity Level in Chinese Building Ceramic Tile. Radiation Protection Dosimetry, 112, 323-327. https://doi.org/10.1093/rpd/nch396

[5] United Nations (1993) Sources and Effects of Ionizing Radiation. Report to the General Assembly with Annexes, United Nations, New York.

[6] Erees, F.S., Dayanıklı, S.A. and Çam, S. (2006) Natural Radionuclides in the Building Materials Used in Manisa City, Turkey. Indoor and Built Environment, 15, 495-498. https://doi.org/10.1177/1420326X06069059

[7] Asaduzzaman, K., Khandaker, M.U., Amin, Y.M. and Bradley, D.A. (2016) Natural Radioactivity Levels and Radiological Assessment of Decorative Building Materials in Bangladesh. Indoor and Built Environment, 25, 541-550. https://doi.org/10.1177/1420326X14562048

[8] Llope, W.J. (2011) Activity Concentrations and Dose Rates from Decorative Granite Countertops. Journal of Environmental Radioactivity, 102, 620-629.

https://doi.org/10.1016/j.jenvrad.2011.03.012

[9] Degerlier, M., Karahan, G. and Ozger, G. (2008) Radioactivity Concentrations and Dose Assessment for Soil Samples around Adana, Turkey. Journal of Environmental Radioactivity, 99, 1018-1025. https://doi.org/10.1016/j.jenvrad.2007.12.015

[10] Lu, X.W. (2005) Radioactive Analysis of Cement and Its Products Collected from Shaanxi, China. Health Physics, 88, 84-86. https://doi.org/10.1097/01.HP.0000142498.08451.c8

[11] Amrani, D. and Tahtat, M. (2001) Natural Radioactivity in Algerian Building Materials. Applied Radiation and Isotopes, 54, 687-689. https://doi.org/10.1016/S0969-8043(00)00304-3

[12] Khandaker, M.U., Jojo, P.J., Kassim, H.A. and Amin, Y.M. (2012) Radiometric Analysis of Construction Materials Using HPGe Gamma-Ray Spectrometry. Radiation Protection Dosimetry, 152, 33-37. https://doi.org/10.1093/rpd/ncs145

[13] Krstic, D., Nikezic, D., Stevanovic, N. and Vucic, D. (2007) Radioactivity of Some Domestic and Imported Building Materials from South Eastern Europe. Radiation Measurements, 42, 1731-1736. https://doi.org/10.1016/j.radmeas.2007.09.001

[14] Solak, S., Turhan, S., Uqur, F.A., Goren, E., Gezer, F., Yeqingil, Z. and Yeqingil, I. (2014) Evaluation of Potential Exposure Risks of Natural Radioactivity Levels Emitted from Building Materials Used in Adana, Turkey. Indoor and Built Environment, 23, 594-602. https://doi.org/10.1177/1420326X12448075

[15] Stoulos, S., Manolopoulou, M. and Papastefanou, C. (2003) Assessment of Natural Radiation Exposure and Radon Exhalation from Building Materials in Greece. Journal of Environmental Radioactivity, 69, 225-240. https://doi.org/10.1016/S0265-931X(03)00081-X 
[16] Righi, S., Guerra, R., Jeyapandian, M., Verit, S. and Albertazzi, A. (2009) Natural Radioactivity in Italian Ceramic Tiles. Radioprotection, 44, 413-419.

[17] El-Taher, A. (2012) Assessment of Natural Radioactivity Levels and Radiation Hazards for Building Materials Used in Qassim Area, Saudi Arabia. Romanian Journal of Physics, 57, 726-735.

[18] Ahmed, N.K. (2005) Measurement of Natural Radioactivity in Building Materials in Qena City, Upper Egypt. Journal of Environmental Radioactivity, 83, 91-99. https://doi.org/10.1016/j.jenvrad.2005.03.002

[19] Ademola, J.A. (2008) Determination of Natural Radionuclides Content in Some Building Materials in Nigeria by Gamma-Ray Spectrometry. Health Physics, 94, 43-48. https://doi.org/10.1097/01.HP.0000279601.26386.af

[20] Mollah, A.S., Ahmed, G.U., Husain, S.R. and Rahman, M.M. (1986) The Natural Radioactivity of Some Building Materials Used in Bangladesh. Health Physics, 50, 849-851.

[21] Roy, S., Alam, M.S., Miah, F.K. and Alam, B. (2000) Concentrations of Naturally Occuring Radionuclides and Fission Products in Brick Samples Fabricated and Used in and Around Greater Dhaka City. Radiation Protection Dosimetry, 88, 255-260. https://doi.org/10.1093/oxfordjournals.rpd.a033043

[22] Roy, S., Alam, M.S., Begum, M. and Alam, B. (2005) Radioactivity in Building Materials Used in and around Dhaka City. Radiation Protection Dosimetry, 114, 527-532. https://doi.org/10.1093/rpd/nch471

[23] IAEA (1989) Measurement of Radionuclides in Food and the Environment. Technical Report Series No. 295, Vienna.

[24] Beretka, J. and Mathew, P.J. (1985) Natural Radioactivity of Australian Building Materials, Industrial Wastes and By-Products. Health Physics, 48, 87-95.

https://doi.org/10.1097/00004032-198501000-00007

[25] United Nations (1988) Sources, Effects and Risk of Ionizing Radiation. Report to the General Assembly on the Effects of Atomic Radiation, United Nations, New York.

[26] Krieger, R. (1981) Radioactivity of Construction Materials. Betonwerk Fertigteil-Technik, 47, 468.

[27] European Commission (1999) Radiological Protection Principles Concerning the Natural Radioactivity of Building Materials. Radiation Protection 112, Nuclear Safety and Civil Protection, EC, Geneva.

[28] (1994) Protection against Rn-222 at Home and at Work. ICRP Publication 65. Annals of the ICRP, 23, 1-48.

[29] (1991) Recommendations of the International Commission on Radiological Protection. ICRP Publication 60. Annals of the ICRP, 21, 1-3.

[30] Rizzo, S., Brai, M., Basile, S., Bellia, S. and Hauser, S. (2001) Gamma Activity and Geochemical Features of Building Materials: Estimation of Gamma Dose Rate and Indoor Radon Levels in Sicily. Applied Radiation and Isotopes, 55, 259-265. https://doi.org/10.1016/S0969-8043(00)00384-5

[31] El-Taher, A. (2010) Gamma Spectroscopic Analysis and Associated Radiation Hazards of Building Materials Used in Egypt. Radiation Protection Dosimetry, 138, 166-173. https://doi.org/10.1093/rpd/ncp205

[32] Aslam, M., Gul, R., Ara, T. and Hussain, M. (2012) Assessment of Radiological Hazards of Naturally Occurring Radioactive Materials in Cement Industry. Radiation Protection Dosimetry, 151, 483-488. https://doi.org/10.1093/rpd/ncs018 
[33] Al-Sulaiti, H., Alkhomashi, N., Al-Dahan, N., Al-Dosari, M., Bradley, D.A., et al. (2011) Determination of the Natural Radioactivity in Qatarian Building Materials Using High-Resolution Gamma-Ray Spectrometry. Nuclear Instruments and $\mathrm{Me}$ thods in Physics Research Section A, 652, 915-919.

https://doi.org/10.1016/j.nima.2011.01.020

[34] Flores, O.B., Estrada, A.M., Suarez, R.R., Zerquera, J.T. and Perez, A.H. (2008) Natural Radionuclide Content in Building Materials and Gamma Dose Rate in Dwellings in Cuba. Journal of Environmental Radioactivity, 99, 1834-1837. https://doi.org/10.1016/j.jenvrad.2008.08.001

[35] Lee, S.C., Kim, C.K., Lee, D.M. and Kang, H.D. (2001) Natural Radionuclides Contents and Radon Exhalation Rates in Building Materials Used in South Korea. Radiation Protection Dosimetry, 94, 269-274.

[36] El-Afifi, E.M., Hilal, M.A., Khalifa, S.M. and Aly, H.F. (2006) Evaluation of U, Th, K and Emanated Radon in Some NORM and TENORM Samples. Radiation Measurements, 41, 627-633. https://doi.org/10.1016/j.radmeas.2005.09.014

[37] Kumar, A., Kumar, M., Singh, B. and Singh, S. (2003) Natural Radioactivities of 238U, 232Th and 40K in Some Indian Building Materials. Radiation Measurements, 36, 465-469. https://doi.org/10.1016/S1350-4487(03)00173-2

[38] Kurnaza, A., Kucukomeroglu, B., Keser, R., Okumusoglu, N.T., Korkmaz, F., Karahan, G. and Cevik, U. (2007) Determination of Radioactivity Levels and Hazards of Soil and Sediment Samples in Frtna Valley (Rize, Turkey). Applied Radiation and Isotopes, 65, 1281-1289. https://doi.org/10.1016/j.apradiso.2007.06.001

[39] Arafa, W. (2004) Specific Activity and Hazards of Granite Samples Collected from the Eastern Desert of Egypt. Journal of Environmental Radioactivity, 75, 315-327. https://doi.org/10.1016/j.jenvrad.2004.01.004 